
Pathophysiology of Haemostasis and Thrombosis

\title{
Plasma Tissue Plasminogen Activator and Plasminogen Activator Inhibitor-1 Levels in Acute Myocardial Infarction
}

\author{
Apar Kishor Gantia Anil Pottia Radha Yegnanarayan ${ }^{b}$ \\ aDepartment of Internal Medicine, University of North Dakota, School of Medicine and Health Sciences,

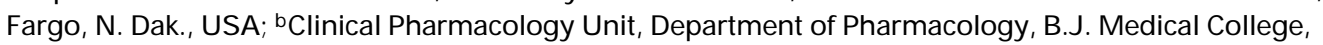 \\ Pune, India
}

\section{Key Words}

Tissue plasminogen activator . Plasminogen activator inhibitor-1 - Circadian rhythm - Myocardial infarction, acute

\begin{abstract}
The cause of the circadian variation in the incidence of acute myocardial infarction (AMI) has not been identified. Tissue plasminogen activator (t-PA) and plasminogen activator inhibitor-1 (PAI-1) have opposing effects on thrombi. Hence, the extent of the clot, the size of the infarct and outcome of patients could depend on t-PA and PAI-1 levels. In an effort to elucidate the pathophysiologic basis of circadian variation of AMI, we investigated the presence of a possible corresponding circadian variation in the levels of endogenous t-PA and PAI-1 in patients diagnosed to have AMI and the effects of hypertension, diabetes and site of the infarct on these levels. We estimated the levels of t-PA and PAI- 1 in platelet-poor plasma of 42 patients with AMI on admission, using the enzyme-linked immunosorbant assay. Although not statistically significant, patients having an AMI in the morning hours had the highest t-PA:PAI-1 ratio. The normal circadian variation in PAI-1 levels was lost in patients with AMI, probably due to the disease
\end{abstract}

process. Also, the t-PA levels in hypertensive patients were significantly lower than in nonhypertensives. PAI-1 levels were also significantly lower in patients with anteroseptal than in inferior and anterolateral AMI. This relationship between the fibrinolytic potential and the site of infarction needs further study. Furthermore, t-PA levels on admission were significantly lower in survivors and may have a predictive value in determining the outcome.

Copyright $\odot 2002$ S. Karger AG, Basel

\section{Introduction}

The occurrence of acute myocardial infarction (AMI) shows a circadian variation with the peak incidence (of onset) in the morning hours. The frequency of infarction in this time period is $1.5-3$ times higher than that observed during other times of the day $[1,2]$. The exact cause of this variation is not known, although a number of hypotheses have been proposed, which include a rise in arterial pressure leading to rupture of the atheromatous plaques, increased coronary tone, increased platelet aggregability and lowest fibrinolytic activity $[3,4]$.

Clot lysis and vessel repair begin immediately after the formation of the definitive hemostatic plug. Tissue plas-

\begin{tabular}{ll}
\hline KARGER & ( ) 2002 S. Karger AG, Basel \\
Fax +4161306 1234 $34-8832 / 02 / 0322-0080 \$ 18.50 / 0$ \\
$\begin{array}{l}\text { E-Mail karger@karger.ch } \\
\text { www.karger.com }\end{array}$ & $\begin{array}{l}\text { Accessible online at: } \\
\text { www.karger.com/journals/pht }\end{array}$
\end{tabular}

Apar Kishor Ganti, MD

Department of Internal Medicine, University of North Dakota

School of Medicine and Health Sciences

1919 Elm Street N, Fargo, ND 58102 (USA)

Tel. +1 701293 4130, Fax +1 701293 4145, E-Mail aganti@medicine.nodak.edu 
Table 1. t-PA and PAI-1 levels: variation with time of the day (mean $\pm \mathrm{SD})$

\begin{tabular}{llll}
\hline Time, h & $\begin{array}{l}\mathrm{t}-\mathrm{PA} \\
\mathrm{ng} / \mathrm{ml}\end{array}$ & $\begin{array}{l}\text { PAI-1 } \\
\mathrm{ng} / \mathrm{ml}\end{array}$ & $\begin{array}{l}\text { Coefficient of } \\
\text { correlation }\end{array}$ \\
\hline $04.00-10.00(\mathrm{n}=15)$ & $19.15 \pm 12.78$ & $60.04 \pm 23.55$ & -0.16 \\
$10.00-16.00(\mathrm{n}=12)$ & $20.39 \pm 14.54$ & $65.46 \pm 17.25$ & 0.08 \\
$16.00-22.00(\mathrm{n}=12)$ & $11.76 \pm 8.1$ & $58.93 \pm 22.9$ & 0.22 \\
$22.00-04.00(\mathrm{n}=3)$ & $23.08 \pm 8.94$ & $82.54 \pm 32.79$ & 0.64 \\
\hline
\end{tabular}

minogen activator (t-PA), which diffuses from the cells, is the principal activator of plasminogen and subsequent fibrinolysis. The endothelial cells also release plasminogen activator inhibitor-1 (PAI-1), which directly blocks the action of tP-A [5]. Hence the extent of the clot and consequently the size of the infarct and the ultimate outcome of the patient depend on the levels of t-PA and PAI1 to some extent. The levels of these two modulators have been shown to follow a circadian rhythm in human beings with the lowest levels of t-PA seen at about 6 a.m., while those of PAI- 1 between 3 and 4 p.m. [6, 7].

The present study was undertaken to (1) examine the presence of a circadian variation in the levels of endogenous t-PA and PAI-1 levels in the patients of AMI, (2) examine these levels in different subgroups of patients with AMI, namely those having hypertension and diabetes mellitus, and (3) correlate the levels of t-PA and PAI-1 on admission with patient survival.

\section{Methods}

The study was conducted in the coronary care units of three hospitals over a period of 2 months.

Newly diagnosed patients with AMI with onset of symptoms no more than $6 \mathrm{~h}$ prior to admission were included in the study. The diagnosis of myocardial infarction was made on the basis of the patient's history, abnormalities on an electrocardiogram and CPKMB levels. On admission after informed consent, blood was collected in $0.1 M$ trisodium citrate $9: 1$ and centrifuged at 2,500 $\mathrm{g}$ for $15 \mathrm{~min}$. The supernatant plasma was stored at $-20^{\circ} \mathrm{C}$ till assays for estimation of t-PA and PAI-1 were performed within a maximum period of 2 months.

The t-PA and PAI-1 assays were performed based on a double antibody principle similar to ELISA [8, 9]. The assays were performed using TintElize ${ }^{\circledR}$ kits (Biopool). The patients were followed up till discharge from the hospital or till death, and any significant event was recorded.

Depending upon the time of onset of symptoms, the patients were divided into four groups: group I: onset between 04.00 and $10.00 \mathrm{~h}$, group II: onset between 10.00 and $16.00 \mathrm{~h}$, group III: onset between 16.00 and $22.00 \mathrm{~h}$ and group IV: onset between 22.00 and $04.00 \mathrm{~h}$.

The mean t-PA and PAI-1 level for each group was obtained. The coefficient of correlation between t-PA and PAI-1 levels was also obtained for each group. Similarly the effect of sex, presence of hypertension or diabetes on the above parameters was studied.

The site of infarction was decided based upon the changes suggestive of infarction on ECG. Changes in leads $V_{1}-V_{6}$ were labeled transanterior, $\mathrm{V}_{1}-\mathrm{V}_{4}$ anteroseptal, $\mathrm{V}_{3}-\mathrm{V}_{6}$ anterolateral, leads II, III, aVF inferior, while changes in leads $\mathrm{V}_{5}, \mathrm{~V}_{6}$, I and aVL were included in lateral wall infarction. The effect of site of infarction on the above levels was studied. A correlation of these levels on patient outcome was also performed. The data was analyzed using the Wilcoxon rank sum test and analysis of variance was used for comparisons between t-PA and PAI-1 levels during the various times of the day.

The local ethics committee approved the protocol and there was no interference with the intended treatment schedule.

\section{Results}

A total of 42 patients, 28 male and 14 female, were included in the study. The mean age of the patients was 57.24 years (range $27-80$ years). The assay of all samples had to be performed simultaneously. Since blood could be stored only for a period of 2 months after collection in order to obtain most accurate results, the number of patients included is low.

There was early morning preponderance in the time of onset of symptoms, with 15 patients reporting first evidence of chest pain or related symptoms in the time interval between 04.00 and $10.00 \mathrm{~h}$, while only 3 patients had onset of symptoms between 22.00 and $04.00 \mathrm{~h}$.

5 patients had a previous history of ischemic heart disease, 2 patients were diabetic and 8 had hypertension. 3 patients were hypertensive and diabetic, 2 had a history of hypertension and ischemic heart disease and 2 patients had a history of all three disorders. Out of 42 patients, 15 had inferior wall infarction, 8 patients each had an anteroseptal and anterolateral infarction, and 6 had a transanterior infarction while 4 patients had a pure lateral wall infarction.

t-PA and PAI-1 levels were lowest in the 16.00-22.00 h group $(11.76 \pm 8.1$ and $58.93 \pm 22.9 \mathrm{ng} / \mathrm{ml}$, respectively $)$ and highest in the 22.00-04.00 h group (23.08 \pm 8.94 and $82.54 \pm 32.79 \mathrm{ng} / \mathrm{ml}$, respectively) (table 1 ). 
Table 2. Effects of various factors such as sex, presence of hypertension and diabetes, site of the infarct, and survival on the initial levels of t-PA and PAI-1 (mean $\pm \mathrm{SD})$

\begin{tabular}{|c|c|c|c|}
\hline & $\begin{array}{l}\mathrm{t}-\mathrm{PA} \\
\mathrm{ng} / \mathrm{ml}\end{array}$ & $\begin{array}{l}\text { PAI-1 } \\
\mathrm{ng} / \mathrm{ml}\end{array}$ & $\begin{array}{l}\text { Coefficient of } \\
\text { correlation }\end{array}$ \\
\hline \multicolumn{4}{|l|}{ Sex } \\
\hline Male $(\mathrm{n}=28)$ & $17.47 \pm 12.01$ & $64.67 \pm 24.34$ & 0.13 \\
\hline Female $(n=14)$ & $18.46 \pm 13.13$ & $59.28 \pm 17.96$ & 0.08 \\
\hline \multicolumn{4}{|l|}{ Diabetes mellitus } \\
\hline Diabetics $(n=7)$ & $14.33 \pm 8.39$ & $64.21 \pm 22.09$ & -0.52 \\
\hline Nondiabetics $(\mathrm{n}=35)$ & $18.5 \pm 12.83$ & $62.61 \pm 22.72$ & 0.14 \\
\hline \multicolumn{4}{|l|}{ Hypertension } \\
\hline Hypertensive $(\mathrm{n}=15)$ & $12.81 \pm 7.86^{*}$ & $65.31 \pm 20.6$ & 0.27 \\
\hline Nonhypertensive $(\mathrm{n}=27)$ & $20.57 \pm 13.46$ & $61.53 \pm 23.54$ & 0.23 \\
\hline \multicolumn{4}{|l|}{ Survival } \\
\hline Dead $(n=4)$ & $34.13 \pm 16.38^{* *}$ & $80.68 \pm 16.38$ & -0.61 \\
\hline Survivors $(\mathrm{n}=38)$ & $16.08 \pm 10.48$ & $61.0 \pm 21.95$ & 0.02 \\
\hline Inferior $(n=15)$ & $17.18 \pm 10.18$ & $71.69 \pm 20.41^{++}$ & 0.1 \\
\hline \multicolumn{4}{|l|}{ Site of the infarct } \\
\hline Transanterior $(n=6)$ & $24.41 \pm 18.88$ & $59.27 \pm 30.32$ & 0.16 \\
\hline Anteroseptal $(n=8)$ & $13.67 \pm 4.89$ & $44.08 \pm 19.41$ & 0.06 \\
\hline Anterolateral $(\mathrm{n}=8)$ & $21.53 \pm 16.57$ & $69.38 \pm 16.12^{+}$ & -0.23 \\
\hline Lateral $(n=4)$ & $10.98 \pm 6.18$ & $58.25 \pm 18.54$ & -0.79 \\
\hline
\end{tabular}

Males had lower t-PA and higher PAI-1 levels (17.47 \pm 12.01 and $64.67 \pm 24.34 \mathrm{ng} / \mathrm{ml}$ ) as compared to females $(18.46 \pm 13.13$ and $59.28 \pm 17.96 \mathrm{ng} / \mathrm{ml}$, respectively) (table 2).

Diabetic patients had lower t-PA and higher PAI-1 levels $(14.33 \pm 8.39$ and $64.21 \pm 22.09 \mathrm{ng} / \mathrm{ml}$, respectively) as compared to nondiabetics (18.5 \pm 12.83 and $62.61 \pm$ $22.72 \mathrm{ng} / \mathrm{ml}$, respectively). Also diabetics showed a negative correlation between t-PA and PAI-1 $(\mathrm{r}=-0.52)$. This, however, was not statistically significant (table 2).

Hypertensive patients had significantly lower levels of t-PA as compared to nonhypertensives $(12.81 \pm 7.86 \mathrm{vs}$. $20.57 \pm 13.46 \mathrm{ng} / \mathrm{ml} ; \mathrm{p}<0.05)$ and higher levels of PAI-1 $(65.31 \pm 20.6$ vs. $61.53 \pm 23.54 \mathrm{ng} / \mathrm{ml})$. This result, however, was not statistically significant (table 2 ).

Patients with lateral wall infarction had lowest t-PA levels $(10.98 \pm 6.18 \mathrm{ng} / \mathrm{ml})$ and t-PA:PAI-1 ratio $(0.23 \pm$ $0.2)$. PAI-1 levels were lowest in the anteroseptal group $(44.08 \pm 19.41 \mathrm{ng} / \mathrm{ml})$. These levels were significantly lower than those in the inferior wall infarction group $(71.69 \pm 20.41 \mathrm{ng} / \mathrm{ml} ; \mathrm{p}<0.01)$ and the anterolateral infarction group $(69.38 \pm 16.12 \mathrm{ng} / \mathrm{ml} ; \mathrm{p}<0.05)$ (table 2).

4 patients, 2 from the 10.00-16.00 h group and 1 each from the $04.00-10.00 \mathrm{~h}$ and the $16.00-22.00 \mathrm{~h}$ group, expired during the hospitalization period itself. The patients who died during the course of the illness showed a significantly higher level of t-PA antigen $(34.13 \pm 16.38$ $\mathrm{ng} / \mathrm{ml})$ as compared to those who survived (16.08 \pm 10.48 $\mathrm{ng} / \mathrm{ml} ; \mathrm{p}=0.01)$. They also had higher levels of PAI-1 as compared to survivors $(80.68 \pm 16.38$ vs. $61.0 \pm 21.95$ $\mathrm{ng} / \mathrm{ml})$, though not statistically significant $(\mathrm{p}=0.07)$ (table 2).

\section{Discussion}

The PAI-1 levels observed in our study were higher than the normal values obtained by estimation with this method $(18 \pm 10 \mathrm{ng} / \mathrm{ml}$ with range of 4-43 ng/ml) [8]. Also, the t-PA antigen levels observed were higher than the normal levels observed in the 55- to 64-year age group $(8.6 \mathrm{ng} / \mathrm{ml}$ in males and $7.6 \mathrm{ng} / \mathrm{ml}$ in females) $[9,10]$.

These two observations correlate well with the findings of previous studies, which showed significant rises in the levels of t-PA antigen and PAI-1 antigen levels, in patients suffering from peripheral arterial disease [11] and coronary artery disease [12-15]. This finding also is in concordance with the findings of Geppert et al. [16] and Hoffmeister et al. [17], who found that the t-PA levels were 
significantly higher in patients with unstable angina as compared to those with stable angina. In fact, based on in vitro data demonstrating a reactive release of t-PA from the vascular wall after increase in thrombin concentration [18], activation of thrombin in patients with acute coronary syndromes is a possible explanation for systemically elevated t-PA antigen concentrations in this subgroup [19, 20]. Our findings also concur with those of Chandler and Stratton [21] who found that postmyocardial infarction patients had higher levels of total t-PA antigen (bound and free t-PA) and increased PAI-1 activity. In contrast to many other studies, we did not find a significant positive correlation between the levels of t-PA and PAI-1 [15, 2224]. Our findings, however, confirm that there is impairment in the fibrinolytic potential (raised PAI-1 antigen levels which correlate with PAI-1 activity, and raised t-PA antigen levels [11]) in patients with AMI [10] despite an activation of the fibrinolytic system [12].

The circadian variation in the levels of PAI- 1 seen in normal individuals [7] was not seen in our study, although the levels in the 16.00-22.00 h group were lower than in the other groups. No significant variation is seen either in the t-PA antigen levels, although the lowest values were seen in the 16.00-22.00 $\mathrm{h}$ group. Males showed a higher level of PAI-1, thereby indicating a higher impairment in the activation of the plasminogen system as compared to females. These values were, however, not statistically significant.

Interestingly, there was a significant difference in the PAI-1 levels amongst the different groups based on the site of infarction. The groups having inferior wall and anterolateral wall infarction had significantly higher impairment of plasminogen activation as compared to the anteroseptal group ( $\mathrm{p}<0.01$ and $\mathrm{p}<0.05$, respectively). There are no previous studies available showing alterations of any parameters based on the site of infarction. It may be possible that these findings may be artifactual, occurring only because of the small size of our study. But this factor seems interesting and needs further elaboration, with methods determining the site of infarction more sophisticated and more accurate than the ones used in our study.

Hypertensive patients showed significantly lower levels of t-PA antigen, which may signify impairment in the plasminogen activation. Hypertension is associated with accelerated atherosclerosis and endothelial injury, which may lead to decreased synthesis and release of t-PA, thereby predisposing to an increased incidence of thrombotic episodes.
In diabetic patients, the levels of PAI-1 were higher as compared to nondiabetics although not statistically significant. This correlates well with the findings of Park et al. [25], who found no significant difference in the levels of t-PA and PAI-1 amongst diabetic and nondiabetic individuals. Although Jokl et al. [26] and Schneider et al. [27] have reported an increase in PAI-1 levels in diabetic patients, obesity rather than diabetes mellitus seems to be the cause for such an increase [21].

The patients who did not survive the episode showed a significantly higher level of t-PA antigen along with a nonsignificant rise in PAI-1 activity, as compared to survivors. This is similar to the findings of Fernandez et al. [28], who found the t-PA concentration to be a factor for poor prognosis over a period of 2 years after an infarction. This could be an important predictor of the outcome of the patient, although further studies need to be conducted with a large number of patients in order to establish this point and also establish a cutoff level below which the outcome would be favorable.

Our study reiterates the fact that there is an early morning increase in the incidence of AMI. There is an attenuation of the normal circadian variation in the PAI-1 levels, among patients with AMI. There appears to be a relation between the fibrinolytic potential and the site of infarction, a point that needs further investigation. Hypertension is associated with lower levels of t-PA antigen, probably due to decreased synthesis by the damaged endothelium, while nonobese diabetics do not show the rise in PAI-1 levels otherwise seen in obese insulin-resistant diabetic patients. t-PA levels are raised in patients who had an adverse outcome and hence t-PA levels on admission could prove to be a valuable predictor of patient outcome in patients with AMI.

\section{Acknowledgments}

The authors are highly grateful to Dr. P.V. Sathe, Ex-Director, Medical Education and Research, Government of Maharashtra, for providing State Research grant to Radha Yegnanarayan for the study. We thank the Departments of Medicine, B.J. Medical College, Pune, K.E.M. Hospital, Pune, and Ruby Hall Clinic, Pune. Thanks are also due to Dr. A. Roy, National Institute of Virology, Pune, and Dr. K.S. Nandakumar and Dipshika Chakraborty, National Centre for Cell Sciences, Pune, for assisting in the assays. 


\section{References}

1 Leizorovicz A, Decousus H: Circadian changes of myocardial infarction. Arch Mal Coeur Vaiss 1993;86(spec No 3):35-39.

2 Muller JE, Stone PH, Turi ZG, Rutherford JD, Czeisler CA, Parker C, Poole WK, Passamani E, Roberts R, Robertson T: Circadian variation in the frequency of onset of acute myocardial infarction. N Engl J Med 1985;313:13151322.

3 Muller JE: Morning increase of onset of myocardial infarction. Implications concerning triggering events. Cardiology 1989;76:96-104.

4 Mulcahy D, Purcell H, Fox K: Should we get up in the morning? Observations on circadian variations in cardiac events. Br Heart J 1991; 65:299.

5 Handin RI: Bleeding and thrombosis; in Fauci AS, Braunwald E, Isselbacher KJ, et al (eds) Harrison's Principles of Internal Medicine, ed 14. McGraw-Hill International Edition, 1998, pp 339-345.

6 Adreotti F, Kluft C: Circadian variation of fibrinolytic activity in blood. Chronobiol Int 1991;8:336-351.

7 Juhan-Vague I, Alessi MC, Raccah D, Aillaud MF, Billerey M, Ansaldi J, Philip-Joet C, Vague P: Daytime fluctuations of plasminogen activator inhibitor 1 (PAI-1) in populations with high PAI-1 levels. Thromb Haemost 1992; 67:76-82.

8 DeClerk PJ, Alessi MC, Verstreken M, Kruithof EK, Juhan-Vague I, Collen D: Measurement of plasminogen activator inhibitor-1 in biologic fluids with a murine monoclonal antibody-based enzyme-linked immunosorbant assay. Blood 1988;71:220-225.

9 Bergsdorf N, Nilsson T, Wallen P: An enzymelinked immunosorbant assay for determination of tissue plasminogen activator applied to patients with thromboembolic disease. Thromb Haemost 1983;50:740-744.

10 Ridker PM, Vaughan D, Stampfur M, Manson JE, Hennekens $\mathrm{CH}$ : Endogenous tissue type plasminogen activator and risk of myocardial infarction. Lancet 1993;341:1165-1168.
11 Smith FB, Lee AJ, Rumley A, Fowkes FG, Lowe GD: Tissue plasminogen activator, plasminogen activator inhibitor and risk of peripheral arterial disease. Atherosclerosis 1995;115: 35-43.

12 Stein D, Heins M, Schoebel FC, Pels K, Jax TW, Stiegler H, Reinauer H, Strauer BE, Leschke M: Activation of the fibrinolytic system in patients with coronary artery disease and hyperfibrinogenemia. Thromb Haemost 1997;77:970-974.

13 Jansson JH, Nilsson K, Olofsson BO: Tissue plasminogen activator and other risk factors as predictors of cardiovascular events in patients with severe angina pectoris. Eur Heart J 1991; 12:157-161.

14 Jansson JH, Olofsson BO, Nilsson TK: Predictive value of tissue plasminogen activator mass concentration on long-term mortality in patients with coronary artery disease: A 7-year follow-up. Circulation 1993;88:2030-2034.

15 Thompson SG, Kienast J, Pyke SDM, Haverkate F, Van de Loo JCW, for the ECAT Angina Pectoris Study Group: Hemostatic factors and the risk of myocardial infarction or sudden death in patients with angina pectoris. $\mathrm{N}$ Engl $\mathrm{J}$ Med 1995;332:635-641.

16 Geppert A, Graf S, Beckmann R, Hornykewycz S, Schuster E, Binder BR, Huber K: Concentration of endogenous tPA antigen in coronary artery disease: Relation to thrombotic events, aspirin treatment, hyperlipidemia, and multivessel disease. Arterioscler Thromb Vasc Biol 1998;18:1634-1642.

17 Hoffmeister HM, Jur M, Wendel HP, Heller W, Seipel L: Alterations of coagulation and fibrinolytic and kallikrein-kinin systems in the acute and postacute phases in patients with unstable angina pectoris. Circulation 1995;91: 2520-2527.

18 van Hinsburg VWM, Sprengers ED, Kooistra $\mathrm{T}$ : Effect of thrombin in the production of plasminogen activators and plasminogen activator inhibitor-1 by human foreskin microvascular endothelial cells. Thromb Haemost 1987;57: 148-153.

19 Szczeklik A, Dropinski J, Radwan J, Krzanowski M: Persistent generation of thrombin after acute myocardial infarction. Arterioscler Thromb 1992;12:548-553.
20 Merlini PA, Ardissino D, Oltrona L, Broccolino M, Coppola R, Mannucci PM: Heightened thrombin formation but normal plasma levels of activated factor VII in patients with acute coronary syndromes. Arterioscler Thromb Vasc Biol 1995; 15:1675-1679.

21 Chandler WL, Stratton JR: Laboratory evaluation of fibrinolysis in patients with a history of myocardial infarction. Am J Clin Pathol 1994; 102:248-252.

22 Olofsson BO, Dahlen G, Nilsson TK: Evidence for increased levels of plasminogen activator inhibitor and tissue plasminogen activator in plasma of patients with angiographically verified coronary artery disease. Eur Heart J 1989; 10:77-82.

23 Salomaa V, Stinson V, Kark JD, Folsom AR, Davies CE, Wu KK: Association of fibrinolytic parameters with early atherosclerosis: The ARIC study. Circulation 1995;91:284-290.

24 Angleton P, Chandler WL, Schmer G: Diurnal variation of tissue-type plasminogen activator and its rapid inhibitor (PAI-1). Circulation 1989;79:101-106.

25 Park YS, Park S, Park KS, Kim SY, Lee HK, Koh CS, Min HK, Kim JQ: The effect of obesity on fibrinolytic activity and plasma lipoprotein (a) levels in patients with type 2 diabetes mellitus in Korea. Diabetes Res Clin Pract 1994;24:25-31.

26 Jokl R, Klein RL, Lopes-Virella MF, Colwell JA: Release of platelet plasminogen activator inhibitor-1 in whole blood is increased in patients with type II diabetes. Diabetes Care 1995;18:1150-1155.

27 Schneider DJ, Nordt TK, Sobel BE: Attenuated fibrinolysis and accelerated atherogenesis in type II diabetic patients. Diabetes 1993;42:17.

28 Fernandez AP, Marin OF, Marco VP, Lujan MJ: Tissue plasminogen activator as a prognostic factor in myocardial infarct patients. Rev Clin Esp 1999;199:215-217. 